\title{
Chapter 21 \\ Promoting Investment in the European Union, Evaluating the Juncker Plan
}

\author{
Stephany Griffith-Jones
}

\begin{abstract}
This chapter analyzes the Juncker Plan, in particular, the European Fund for Strategic Investment (EFSI), highlighting its achievements in expanding investment in the European Union and challenges in mitigating future risks to the European Investment Bank, as well as maximizing the development impact of its activities.
\end{abstract}

\section{Introduction}

Economic growth and specifically investment levels in the European Union (EU) recovered far more slowly after the financial crisis than, for example, in the United States or even more in Asia (Klein 2019). Total investment is too low in the European Union. For some time before the crisis, the EU had relatively low levels of investment, reaching $22.5 \%$ of GDP in 2006. In emerging and developing economies, it reached $26.7 \%$ in the same year. But the 2007-2009 financial crisis and the Eurozone debt crisis dragged it sharply downward. By 2016, total EU investment had fallen to $19.9 \%$ of GDP, even as emerging and developing countries were at $24.5 \%$. The fall in public investment has been striking in the Eurozone-over 20\% between 2007 and 2016. The trend was most notable in the crisis-hit countries. For example, gross public investment in Greece fell from a high 4.9\% of GDP in 2006 to $3.1 \%$ in 2016 - and that of a far smaller GDP due to a major contraction. In Spain, the same ratio declined even more dramatically, from $4.3 \%$ in 2006 to $1.4 \%$ in 2016 . Net public investment - gross investment minus depreciation-was actually negative in the Eurozone in 2016. Some member states were, of course, affected more, but this decrease in public investment represented a worrying trend common across most of the Eurozone. Even in Germany, gross public investment was low and below the Eurozone average.

\footnotetext{
S. Griffith-Jones $(\bowtie)$

Initiative for Policy Dialogue, Columbia University, New York, USA

Institute of Development Studies, Sussex University Brighton, Brighton, UK

e-mail:sgj2108@columbia.edu
} 
The reasons for the decline in public investment across Europe were clear. In crisis-wracked countries, austerity forced on countries including Greece, Spain, Portugal and Ireland compelled large cuts in government expenditures. It was impossible to cut the lifelines on which so many depend, for instance, assistance in housing. The consequences of these cutbacks are felt immediately; it will be years before the consequences of cutbacks in public investment are noted. Therefore, politicians focus cutbacks disproportionately on investment. But even in countries with public finances that would have permitted greater investment, notably Germany, ideology prevented higher public investment, that would have both increased aggregate demand and immediate growth, as well as future growth.

In 2015, the European Commission acknowledged the Growth and Stability Pact served the Eurozone badly and published a framework allowing countries to deviate from the anti-deficit rules to promote investment. Though the flexibility introduced was welcome, the problem that the Pact curtails productive investment at precisely the time it is needed most remained. Even worse, it curtails productive investment at precisely the time when the social benefit cost ratio is highest, and when the opportunity cost of these investments is low. Public investments are not crowding out (displacing) either private investments or consumption, because it can use resources that otherwise would be idle. On the contrary, public investments crowd in private investment.

Even in financial terms, economic downturns are the time to make investment. With long-term government bond yields close to zero, it would have been easy to find public investment projects that generate a much higher return. By failing to increase government investments in this period, Europe missed an opportunity, which was reflected in the far lower growth rate it had than for example the United States, even though the financial crisis originally came from the United States. During and after the Eurozone debt crisis, problems with low aggregate demand, economic uncertainty and a weakened private banking system contributed also to low levels of private investment. The reduction was sharpest in the southern Eurozone countries, with private investment decreasing from 22\% of GDP in 2007 to $14 \%$ in 2014 - but the picture was almost uniformly grim across Europe.

After the Eurozone debt crisis started, creditor Governments (especially Germany, but also Holland, and Finland) were unwilling to modify in a significant way the so-called Growth and Stability Pact, so as to allow countries to increase their national fiscal deficits to fund higher public investment; this was argued would have been a desirable path forward by many academics, such as Peter Bofinger and Gustav Horn in Germany, as well as Paul Krugman and Joseph Stiglitz internationally (e.g. for the latter see Stiglitz 2019), as well as of course the governments and academics of crisis countries and France. At the same time, it was difficult formally to expand EU level of investment (e.g. via Structural Funds), because the European Union budget had been approved until 2020; of course supplementary funds could have been made available if member states were willing, again, this was blocked especially by creditor countries. Simultaneously, in the wake of the financial crisis of 2007-2009, and the Eurozone debt crisis of 2009-2010, there had been renewed support for public regional and national development banks, as the limitations and 
problems of a purely private financial sector became more evident to different strands of economic thinking (Griffith-Jones and Ocampo 2018).

In this context, the European Investment Bank Group (EIB), with its long track record of successfully playing a key and large role in funding intra-European infrastructure, including renewable energy, Small and medium enterprises (SMEs) and innovation, took on renewed importance. Thus, an indirect route, using the European Investment Bank, was chosen to encourage investment, especially private one, in the European Union. A first step was the doubling of paid-in capital of EIB by all member states in 2012, which allowed EIB to expand its lending (Griffith-Jones and Kollatz 2012). The public contribution by member states was limited, but was reported to generate far higher finance and investment via leverage with private resources.

Furthermore, as a more traditional Keynesian response (at both national and Eurozone levels) was not deemed acceptable, EFSI was created, as a sort of Keynesian mechanism "sans dire", and with no or little additional public money, but a large potential impact, due to the effect of leverage. Indeed, the EIB is implementing the European Fund for Strategic Investment (EFSI), which is the core of the Investment Plan for Europe (the "Juncker Plan"), and aims to fund much needed investment for Europe, especially in the wake of devastating austerity (phase 1) as well as to facilitate much needed structural change to a greener, more dynamic and more inclusive economy (phase 2). Emphasis was placed on financing riskier investment, for example in the crisis-hit countries, as well as in the newer member countries. In this context, the Juncker Plan seems broadly highly successful (Fig. 21.1).

The EFSI is a EUR 26 billion guarantee from the EU budget, which comes mainly from existing research and innovation and transport budget lines, complemented by a EUR 7.5 billion allocation of the EIB's own capital, given EU budget limitations. The total amount of EUR 33.5 billion aims to leverage additional investment of at least EUR 500 billion between 2015 and 2020. Essentially a small fraction of the EU budget is used as a guarantee for EIB projects that have a higher risk profile than the usual ones. The aim is to push the EIB to finance valuable but risky projects that could not secure funding on their own, to adopt a junior position with respect to co-financiers, to reduce the risks taken by private investors and to increase the chances of attracting their investment (interview material). EFSI has two components, the innovation and infrastructure window managed by the EIB, and the SME window implemented by the EIF (European Investment Fund). ${ }^{1}$

It is interesting that about a fourth of the transactions of EFSI are estimated to have been channeled through national development banks (NDBs), thus increasing the role these banks play in the EU. They will play an even larger role in InvestEU. Indeed, in InvestEU, the EU guarantee can be granted directly to NDBs, up to a certain proportion. If properly done, increasing the loan volume through leverage is a positive thing, as it should facilitate higher levels of investment. However, there is a risk that the greater the loan volume achieved through involving

\footnotetext{
${ }^{1}$ https://www.eif.org/what_we_do/efsi/index.htm. Accessed 08 March 2020.
} 

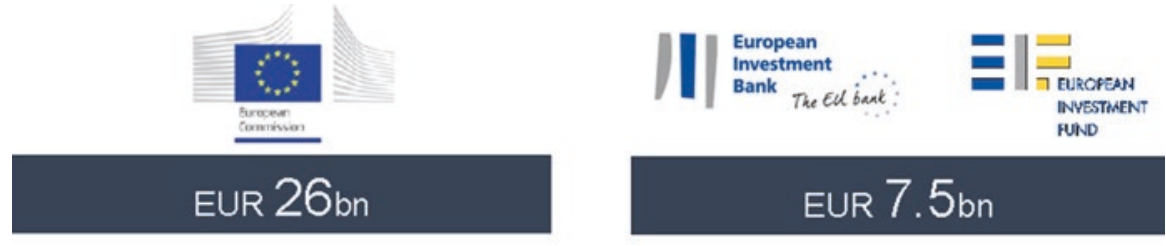

\section{EFSI - European Fund for Strategic Investments EUR 33.5bn}

\section{Financing: EUR $100_{b n}$}

\section{Final investments: EUR $500_{\text {bn }}$}

Fig. 21.1 Structure of EFSI. (Source: Interview material)

private intermediaries, the more indirect the operations become, and the less strategic direction the European institutions are able to exert over projects. In this sense, there is some trade-off between loan volume and policy steer.

For the next EU budget (2021-2027), the Commission is developing the continuation of EFSI, with some modifications as the InvestEU Fund. The InvestEU Fund will consolidate various EU financing programs and instruments into one, which should lead to economic efficiency gains, and politically may be more desirable, due to greater decentralization; InvestEU will follow the Juncker Plan model of mobilizing additional private funds for additional investment. This is expected to allow the EU budget to provide a $€ 30$ billion guarantee, expected to crowd in an additional total of $€ 650$ billion of mainly private investments over the 7-year period. It is argued this will result in investment far greater than is possible via for example public investment, in the context of member states' budget real and perceived constraints, or via conventional EIB activities, as happened before EFSI.

One of the continuous challenges to move beyond the crisis is to restore growth in the European Union, but this should not just be more dynamic but both more sustainable and inclusive growth. Particular priority has rightly been given by the EU to measures and instruments to facilitate a speedy and significant transition to a low carbon economy.

Indeed, the European Commission's Green Deal released in December 2019, and the accompanying Investment Plan (EGDIP), which aims to make the EU into the first climate neutral bloc in the world by 2050 , will be key. The European Investment 
Bank (EIB) as well as the European countries' national development banks (NDBs) - which have been expanding in scale and extension to practically all EU countries - are expected to play a key role, both in funding key investments for the green transformation directly, as well as in catalyzing significant additional private finance (both lending and equity) to low carbon projects.

It is important that the EU as a whole as well as individual EU countries deploy broader policy measures to facilitate finance (both public and private) is redirected and channeled to low carbon or carbon neutral activities. These broader policy measures could, for example, include financial regulatory and fiscal policies that would supplement and support the activity of EIB and NDBs in the green transformation.

In this sense, it is important to have an ambitious design of structural transformation for the EU economies (e.g. in sectors like electro-mobility and renewable energy, and the infrastructure that supports them), with a large impact on lowering carbon emissions to meet the challenges of the climate emergency.

\section{A Bit of History}

The EIB was established in 1958 by the Treaty of Rome, and historically provided infrastructure financing, usually through long-term fixed interest rate loans, backed by member state guarantees. The EIB then broadened its activities and currently focuses on: innovation, SMEs, infrastructure and environment.

The EIB essentially took little risks on its activities and had an AAA credit rating, which it could use to cheaply finance its activities on international financial markets, and then on-lend very cheaply to its customers. It is interesting that even though several member countries were downgraded from AAA (some dramatically like Greece), after the Eurozone debt crisis, the EIB maintained its AAA status, though using lower leverage than in the past (Interview material). The fact that EIB maintains AAA status is very positive from the perspective of the borrowers, as well as its strength as a major EU institution. From the late 1980s/early 1990s, the EIB began changing its business model to take on more risk, as its statute was amended to manage the new European Investment Fund (EIF). The EIF has a unique capital structure, with most of its capital contributed by the European Commission and the EIB, $11.6 \%$ of its capital is owned by public and private financial institutions; most of these are national development banks, but also some large private banks, like Barclays (Interview material). The instruments evolved. The EIB and EIF began giving loan guarantees, relaxing requirements for member state guarantees and using equity instruments. Though guarantees can be problematic, especially if badly structured, or if a big financial crisis happens (where uncorrelated risks become correlated), they have important advantages. Furthermore, it is argued by some that "the biggest risk are grants", because there is in that case certainty the funds will not be paid back. So guarantees have two advantages: firstly, they provide leverage, and secondly, they are like a revolving fund and resources can be used again if there are no major losses. On the other hand, if major losses occur, the provisions are not 
sufficient and guarantees have not been fully priced, then governments (taxpayers) have to pay in the future. Furthermore, there is evidence that, though the EIB and EIF pay fully the price of the European Commission guarantee, it is likely that an important part of EFSI guarantees granted to commercial banks do not price fully their cost. Above all, the pricing of guarantees seems opaque. This is reportedly in contrast with loans, where products are more fully standardized and transparent (Interview material).

The EIB's approach to innovation also changed. Until 2007, innovation was only funded through grants. In 2007, the EC and the EIB set up the Risk Sharing Finance Facility (RSFF) with the stated aim of improving access to finance for activities in the field of R\&D and innovation. It was built on the principle of pari passu (equal) credit risk sharing between the EC and the EIB, which was designed to give the EIB capital relief, and therefore allow it to take more risk by providing loans or guarantees with a sub-investment grade risk profile. This could be said to be the first time EU institutions used financial engineering to make risk-sharing agreements, and became the blueprint for EFSI (interview material).

\section{The Working of EFSI}

EFSI has a high overall multiplier target of $15 x$. The first step is the internal multiplier of $3 \times$, where the EFSI guarantee of 33.5 billion Euros from the European budget is expected to generate 100 billion Euros of EIB financing on international financial markets. The second step is the external multiplier of $5 \times$, where the internal funds of 100 billion are expected to catalyze additional private and public financing to reach a total mobilized investment volume of 500 billion. The external multiplier varies across financial products, so the $5 \times$ target applies to the entire portfolio of operations. The overall multiplier target of $15 x$ is the relation between expected total investment mobilized (500 billion) and the initial EFSI guarantee (33.5 billion) (EIB 2019) (Fig. 21.2).

The EFSI has taken a number of steps including the creation and use of new financial instruments (financial innovation), especially in EIB operations, while EIF operations for SMEs relied mainly on existing instruments; both encourage greater involvement of public and private actors, in particular national development banks (NDBs) and institutional investors. The mobilization of private capital brings potential benefits (achieving higher levels of investment, by "doing more with less fiscal resources"), but also generates potential risks, via contingent liabilities, that need to be properly accounted and provisioned for. In 2014, the RSFF was turned into InnovFin, and both the size of the funds as well as the range of financial products were increased. ${ }^{2}$ COSME, the EU program for Competitiveness of Enterprises and SMEs, operated by EIF, was also set up during 2014-2020, with a budget of $€ 2.3$

\footnotetext{
${ }^{2}$ https://www.eib.org/en/products/blending/innovfin/index.htm. Accessed 08 March 2020.
} 


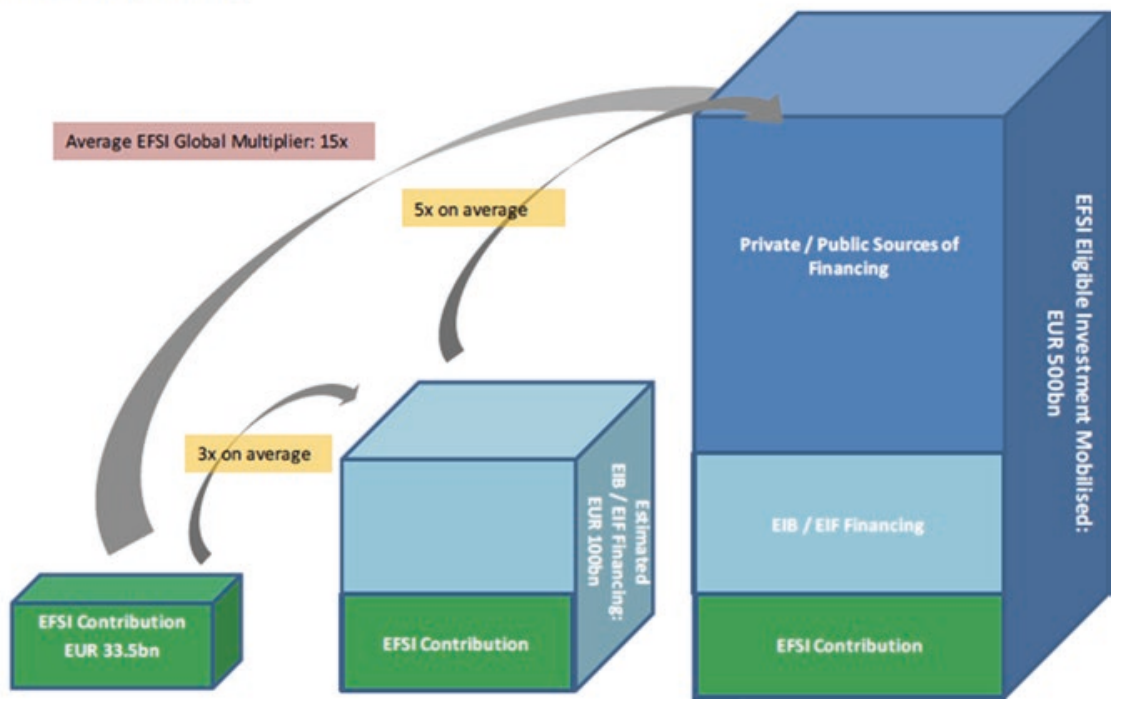

Fig. 21.2 Overall multiplier for EFSI. (Source: EIB 2019a)

billion, in order to provide financing support for SMEs. ${ }^{3}$ COSME has a Loan Guarantee Facility that aims to enable financial institutions to increase loan and lease finance to SMEs, as well as an Equity Facility for Growth that provides risk capital to equity funds that invest in SMEs.

\section{Financial Products}

The EFSI has widened its range of financial products to include not only its traditional loans and guarantees, but also credit enhancement products, using the RSFF blueprint and equity type products (for more details, see Griffith-Jones and Naqvi Forthcoming). Equity type products imply more risk than loans, but have the advantage of also being able to "capture the upside" if projects are more profitable than expected. One such instrument being currently applied is venture debt. The EFSI operational strategy further specifies the different products that the EIB Group can use to deploy EFSI. These include senior and junior loans, risk-sharing instruments and capital market instruments including equity or quasi-equity participations (European Court of Auditors 2019, p. 18).

Under the SME window, EIF continues to rely on existing products already used under COSME, InnovFin and other mandates. It was reportedly an advantage for

\footnotetext{
${ }^{3}$ https://ec.europa.eu/docsroom/documents/9783. Accessed 08 March 2020.
} 
the SME window, EFSI, especially initially, used existing, well-tested product lines. This seemed a wise decision. It may have contributed to the more rapid deployment of EFSI finance for SMEs, especially initially seen as more successful. The EIF's volume of operations has been increased very significantly thanks to EFSI, growing from EUR 3.3 billion in 2014 to EUR 10 billion in 2018, that is more than tripling in 4 years (interview material). EIF's focus is to enhance access to finance for SMEs as part of its EU mandate, but also provides ecosystem support like development of the European venture capital market, as well as the market for business angels, via a fund to co-finance with angels, that helps develop fintech, crowd funding, etc. EIF covers the whole financing chain, starting with funding for seed capital to laterstage growth to mid-cap market, but also is active in more mature markers with guaranteed products. EIF does not finance SMEs directly, but always goes through intermediaries - the guarantee is provided to banks or counter guarantees are provided to guarantee institutions (NDBs mainly like BPI France, KfW). The counterparty has to do riskier business than they would do normally if they get EIF guarantees.

Because COSME was focused on smaller transactions, over one million SMEs have been supported. EFSI support has also not just increased number of SMEs served, but also riskier SMEs, in more countries. Start-ups are often neglected on the side of debt, some sectors are neglected, for example, creative, but even traditional sectors have niches of sectors not well served. Under the infrastructure window, in addition to relying on traditional long-term senior loans (about $60 \%$ of the total), the EIB expanded the use of existing higher-risk products and developed new ones. The EIB has conducted securitized transactions under the infrastructure window in partnership with the EIF. One of the interesting new products is venture debt where EIB provides debt, but there is an equity kicker-if business does well, EIB also gets part of that higher profit, as compensation for taking higher risk, implying this is an instrument where EIB captures the upside, which is clearly desirable, as EIB is not just sharing risks but also profits with private company.

\section{Analytical Framework for Different Risks}

There is a key distinction on the nature of risk that is essential to clarify, both from an analytical point of view and a policy perspective. This should be important to evaluate initiatives like EFSI and InvestEU. There is first the "economic" type of risks; these are basically related to the natural uncertainty related to projects or sectors. These are typically: (1) in infrastructure projects (e.g. risks of construction difficulties and delays, especially in engineering ambitious projects, see for example, Griffith-Jones 1993); (2) "Economic" risks are also very prevalent in the funding of innovative companies, such as start-ups, often based on potentially excellent ideas, but lacking assets for guarantees, and/or track record; (3) Financing SMEs is generally considered riskier in most countries, except in countries like Germany, with decentralized banking systems, which allow for greater knowledge of 
companies. SME financing becomes riskier if financial crisis happens, when the benefits of diversification are reduced; (4) Very importantly, "economic" risks can also relate to sectorial or cross-sectorial innovation that may lead to major increases in productivity and/or significant structural transformation, for example to a greener economy (Mazzucato 2013); (5) Also assuming "economic" risk implies lending to or investing in countries that are (usually temporarily) seen as less creditworthy by financial markets, especially, during, and in the long aftermath of, financial crises or other major shocks.

These "economic" types of risks are in sharp contrast with "financial engineering" risks, created by financial actors, often partly hidden by opaque and complex structures, and whose impact only often emerges ex post in crises' situations. The alleged, and sometimes legitimate, aim may in some cases partly be to increase leverage of public resources, and for this reason may be backed also by policymakers, with the aim of doing "more with less", as in the case of the European Union. However, the main general aim of creating instruments with "financial engineering" risk is to increase profitability for private financial actors, while minimizing their risk of losses. The financial sector, however, must serve the real economy, and financial objectives, for example, the development of capital markets, must never be an end in itself. EFSI and InvestEU must have a greater focus on the final beneficiaries of projects rather than on the private financial intermediaries.

The distinction between "economic" and "financial" risk was less important in the aftermath of the 2008 and Eurozone debt crisis, as there was a great need to counter-cyclically increase lending volume to maintain investment as the private financial sector became risk averse. However, now the private financial sector has become more willing to lend, and even does so at very low margins, there is not much benefit in most countries and sectors to de-risking them further. Indeed, they may even need to be held back from causing a bubble in certain sectors (interview material). However, there remains a need to take "economic risk", especially for sectors important for industrial policy/structural transformation, or developmental objectives, such as green energy, innovative companies or riskier less developed EU countries. Financial risk on the other hand needs to be limited in scale, very carefully evaluated ex-ante, to avoid large contingent liabilities and possible significant losses.

One of the main aims of the Juncker plan and EFSI is to provide finance to valuable projects that would not get financed on private markets, or through normal EIB channels due to their high risk. Although these risky projects might not be bankable in the sense of resulting in short-term profits, they are vital for long-run growth and structural transformation. The Juncker plan envisions doing this by getting the EIB to take on more risk than it normally would. While EFSI (in its phase 1) initially had a counter-cyclical focus in the postcrisis environment, EFSI 2 and InvestEU have more of a structural transformation objective.

The EU institution's matrix for assessing whether this developmental role is being played is to take into account the risk profile of the EIB's financial products, rather than on the beneficiaries. This can be problematic in some cases, as economic and financial risks can at times diverge, and projects that the EIB classified as "high 
risk" according to the EFSI objectives may in fact only be risky in the financial sense. In some cases, the same project was classified as a riskier EFSI project rather than a normal EIB project, purely because the financial products changed to riskier ones (interview material).

While funding projects with economic risk is good, taking excessive financial risk through complex financial products or through too high risk sharing with the private sector creates the danger that the public entities (and ultimately the taxpayers) will bear the risks, while the private sector reaps all the rewards. It could also have negative long-term budgetary implications via contingent liabilities. This leads us to the third issue, which is that of the distribution of risks of losses and profits, between the public actors (in this case, EIB and European Commission funds, for example deployed as guarantees) and the private financial actors (lenders and investors). If with the aim to attract additional private lending or investing, financial products are created that generate too much additional financial risk and transfer too high a proportion of that risk to the public sector (especially without transferring any of the potential upside of profits to the public sector), then this is highly undesirable from a welfare and public policy perspective. This is particularly the case if these instruments lead to high losses, which can only be known ex-post in the future; such losses could be costly to the public sector, if the instruments are not properly priced, and can generate future problems if there are no adequate provisions against such potential future losses. Because many of the projects have long maturities, it is harder to know what the longer term possible losses and thus budgetary implications of the risk-sharing agreements are before loans become due (interview material).

\section{Collaboration with National Development Banks}

The EIB's cooperation with member states' national development banks (NDBs) has been strongly enhanced as part of EFSI, including its leverage strategy. As discussed above, participation of an NDB as a financial intermediary increases EFSI's leverage due to the catalytic effect. NDB participation also helps with overcoming fiscal constraints. Although NDB activities do count as contingent liabilities, they do not count toward the Maastricht criteria (EC 2015). Cooperation between the EIB and NDBs can take four forms: (1) Co-investment, at the project level; (2) Intermediated financing where the EIB provides loans or guarantees to NDBs for on-lending; (3) Risk-sharing instruments where the EIB makes an agreement to cover up to a certain percentage of credit risk associated with a portfolio of loans. This reduces the exposure of the NDB to certain sectors or client segments, and frees up capital and other resources to grant new loans; (4) Collaborative investment platforms that involve joint cooperation among the EIB Group, several NDBs and potentially other IFIs, the latter especially in the context of InvestEU (EIB 2016). 


\section{Distribution of EFSI Resources Between Countries}

Is EFSI a tool that can benefit all Member States? Because the EFSI has been designed to allocate financial support without so-called "political interference" in the selection of projects, it is more prone to support those economies where greater investment opportunities already exist. Since the very beginning of the program, the uneven geographical distribution of its support has been criticized. Larger and richer economies have more experience to develop a greater number of viable projects. By mid-2016, almost all financing granted under the EFSI (92\%) had been allocated to the initial member countries, the EU-15, among which the largest beneficiaries were Italy, Spain and the UK. This is in stark contrast with the "new" EU-13 (mainly the Central and Eastern European countries that joined later), which accounted for a mere $8 \%$ of disbursements.

Although less developed EU countries were initially excluded, the situation seemed to be improving, as special efforts were made in this. Data from the European Parliament shows that while the more advanced Western European countries are the main beneficiaries in terms of absolute investment, once size of the economy and population are accounted for, the distribution is much less concentrated (European Parliament 2017, pp. 13-15). Countries harmed by austerity, including Spain, Portugal, Italy and Greece, now rank among the highest receivers of EFSI investment as a percentage of GDP, which is to be praised. In investment per capita terms, they also remain high, but Central and Eastern European countries, in particular, Romania, Croatia and Hungary, remain lagging behind. Capacity building to overcome discrepancies like these must become one of the key objectives for both the European Investment Bank as an institution and EFSI as a mechanism (GriffithJones and Naqvi Forthcoming).

\section{Conclusion}

Relying on a budgetary allocation of EUR 33.5 billion, EFSI aims to leverage additional investment of at least EUR 500 billion between 2015 and 2020. The plan seems to be broadly on track, with EUR 70.4 billion of financing approved, from which EFSI claims to have mobilized a total of EUR 375.5 billion, as of July $2018 .^{4}$ One important achievement of EFSI is that of the clients it has served, $75 \%$ are new ones, who had never borrowed before from the EIB. This is encouraging, in terms of additionality achieved and new clients. Furthermore, before EFSI, the EIB is reported to have had among its operations only $5 \%$ of risky business; however, by 2018, 20\% of EIB operations are reportedly risky business (interview material). This is a positive achievement, particularly to the extent that increased risk means increased economic risk and not purely financial risk.

\footnotetext{
${ }^{4}$ https://www.eib.org/en/efsi/. Accessed 08 March 2020.
} 
In the context of supporting innovative technologies, with climate mitigation aspects, it is impressive that the EIB has funded $40 \%$ of offshore wind installed capacity in Europe; it often moved to support the more innovative aspects of offshore (larger scale of blades, and even floating offshore wind farms). The EFSI thus has important achievements, including the significant leverage it is providing on scarce EU budget resources, to help provide lending and guarantees to important innovative projects and provide additional resources to countries that have suffered from the Eurozone crisis, or who are new EU members, as well as supporting increased investment in the EU more broadly. It has also allowed the EIF to significantly increase its operations in its important role of catalyzing financing for SMEs.

While the mobilization of private capital brings potential benefits (achieving higher levels of investment, by "doing more with less fiscal resources"), it also generates potential risks, via contingent liabilities, that need to be properly accounted for and provisioned for. The use of opaque new financial instruments can further increase unnecessary "financial" risk, of the type that resulted in the 2007 subprime mortgage crisis, without increasing necessary and valuable "economic" risks. There is also a risk that the greater the loan volume achieved through involving private intermediaries, the more indirect the operations become, and the less strategic direction the European institutions are able to exert over projects.

While funding projects with economic risk is valuable, taking excessive financial risk through complex financial products or through excessive risk sharing with the private sector creates the danger that public entities (and ultimately the taxpayers) will bear the risks, while the private sector reaps all the rewards. This is highly undesirable from a welfare and public policy perspective. If the EIB wants to take more risk, it is key it identifies higher risk projects/sectors/countries, as opposed to higher risk financial products.

\section{References}

EIB (2016). Rules applicable to operations with investment platforms and national promotional banks or institutions. Available at https://www.eib.org/attachments/strategies/efsi_steering_board_rules_applicable_to_operations_with_investment_platforms_and_npbs_or_institutions_en.pdf.

EIB (2019). A. EIB EFSI multiplier methodology calculation. Available at https://www.eib.org/ attachments/strategies/efsi_steering_board_efsi_multiplier_methodology_calculation_en.pdf.

European Commission (2015). 'Working together for jobs and growth: The role of National Promotional Banks (NPBs) in supporting the Investment Plan for Europe'. Communication from the Commission to the European Parliament and the Council. Available at: http://europeanmemoranda.cabinetoffice.gov.uk/files/2015/07/11283-15.pdf.

Griffith-Jones, S. (1993). Loan guarantees for large infrastructure projects: The issues and possible lessons for a European facility. Office for official publications of the European communities. https://stephanygj.net/papers/LoanGuaranteesforLargeInfrastructureProjects1993.pdf. Accessed 1 Mar 2020. 
Griffith-Jones, S., \& Kollatz-Ahnen. (2012). Stimulating Europe. Financial Times, 18 June 2012. http://policydialogue.org/files/publications/papers/Stimulating_Europe_061812.pdf. Accessed 1 Mar 2020.

Griffith-Jones, S., \& Naqvi, N. (Forthcoming). Leveraging policy steer? Industrial policy, risksharing and the European Investment Bank. In D. Mertens, M. Thiemann, \& P. Volberding (Eds.), The reinvention of development banking in the EU. OUP.

Griffith-Jones, S., \& Ocampo, J. A. (Eds.). (2018). The future of national development banks. Oxford: Oxford University Press.

Klein, M. (2019). Italy embraces China and Europe's elites have only themselves to blame. Barron's 5 April 2019. https://www.barrons.com/articles/europes-elites-have-only-themselvesto-blame-for-italys-embrace-of-china-51554481025. Accessed 1 Mar 2020.

Mazzucato, M. (2013). Financing innovation: Creative destruction vs. destructive creation. Industrial and Corporate Change, 22(4), 851-867.

Stiglitz, J. (2019). People, power, and profits: Progressive capitalism for an age of discontent. Penguin UK.

Open Access This chapter is licensed under the terms of the Creative Commons Attribution 4.0 International License (http://creativecommons.org/licenses/by/4.0/), which permits use, sharing, adaptation, distribution and reproduction in any medium or format, as long as you give appropriate credit to the original author(s) and the source, provide a link to the Creative Commons license and indicate if changes were made.

The images or other third party material in this chapter are included in the chapter's Creative Commons license, unless indicated otherwise in a credit line to the material. If material is not included in the chapter's Creative Commons license and your intended use is not permitted by statutory regulation or exceeds the permitted use, you will need to obtain permission directly from the copyright holder. 